\title{
INVITATION TO THE ASTIN COLLOQUIUM 2003 \\ IN BERLIN/GERMANY
}

Dear ASTIN Colleagues,

The XXXIV ${ }^{\text {th }}$ International ASTIN Colloquium will be held in Berlin, the Capital of Germany, from 24 to 27 August 2003. The German Actuarial Association is pleased to invite you to attend this Colloquium.

The Colloquium will be held at the Inter-Continental Hotel, which is located in the heart of the city very close to Kurfürstendamm and Gedächtniskirche. The programme includes an excursion to Potsdam with the beautiful castle of king Friedrich the Great.

The subjects of the scientific discussions during this Colloquium will cover both the theoretical and practical aspects of issues of great topical interest. We hope that the Colloquium will stimulate your curiosity and creativity as actuaries so that you will enrich it with interesting papers and lively contributions.

Several internationally acclaimed speakers (Sören Asmussen, Paul Embrechts, Jean Lemaire, Angus McDonald, Greg Taylor and others) will chair talks on topics of high interest to Non-Life actuaries.

Papers will be accepted on the following topics:

\section{Topic 1: Risk evaluation}

- Measuring risk, identifying risk factors, segmentation of risks

- Profit and loss distributions

- Major and catastrophic losses

- Pricing risk, rate-making

- Health care, genetics

\section{Topic 2: Risk finance and risk transfer}

- Reinsurance

- Financial reinsurance

- Alternative risk transfer

- Insurance derivatives

\section{Topic 3: Risk control}

- Claims reserving

- Ruin theory, solvency

- Asset liability management, dynamic financial analysis

- Overall capital requirements and allocation to portfolio segments

\section{Topic 4: Others}

- Miscellaneous subjects not covered under Topics 1-3 
An ASTIN programme brochure, including full details, hotel information, and a final registration document, will be mailed in early 2003 to applicants who have completed and returned the preregistration form which can be found at the website www.astin2003.de. This website contains many other useful information and links.

At all events, the success of this Colloquium will depend on your presence. We look forward to meeting as many of you as possible.

Yours faithfully,

Christian Hipp

Martin Balleer

Chairperson

Chairperson

Scientific Committee

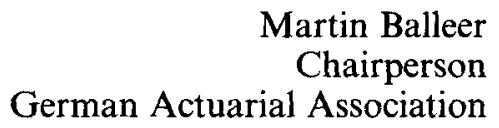

